\title{
Multidimensional Interests in Horizontal Intergovernmental Coordination: The Case of the German Bundesrat
}

\author{
Yvonne Hegele* \\ *University of Konstanz; yvonne.hegele@uni-konstanz.de
}

In the German Bundesrat, an arena of horizontal intergovernmental relations, sixteen Länder governments composed of approximately 170 governmental departments coordinate and negotiate their positions on federal motions. This article analyzes the coordination process and argues that the interests that the actors pursue, as well as the coordination strategies stemming from these interests, are less clear-cut than commonly assumed. Based on a novel network dataset collected by the author, evidence is found for sectoral, political party, and territorial coordination strategies. The main findings are first, that political party coordination in Germany is more frequent than territorial coordination but performs a structuring instead of a substantial function during the coordination process. Second, sectoral coordination mainly takes place at an early stage of the coordination process and is able to solve a bulk of coordination problems by drawing on expert knowledge.

Processes of information exchange and coordination between central governments and sub-state governments are important processes in multilevel polities and determinants of successful multilevel policy-making. These occur not only vertically between the federal government and sub-state governments but also horizontally among sub-states. Poirier, Saunders, and Kincaid $(2015,4)$ argue that intergovernmental relations (IGR) are "the lifeblood of federalism in practice." This is especially true for cooperative federalism as it exists in the German Federal Republic with its system of joint decision-making (Behnke and Kropp 2016). One arena of intergovernmental relations in Germany is the Bundesrat.

The German Bundesrat is the second chamber with territorial representation and an important institution in German politics. Its decisions often trigger or contribute to public discourse, for example, when in 2016 a decision regarding asylum policy and safe countries of origin led to intense public debate. In prior years, the Bundesrat initiated and led prominent attempts to forbid the extreme right party (NPD) or to exclude it from public party financing. Recently, it took a 
resolution to prohibit the sale of diesel engines from 2030 onwards. The examples are manifold and from very different policy areas. The Bundesrat, however, is not a unitary actor but composed of the sixteen Länder governments. Against this background it becomes relevant to analyze how the Bundesrat reaches its decisions. The Bundesrat plenary sessions and their protocols suggest that it is a mere aggregate of individual positions. Real debate hardly ever takes place; some decisions are even taken without any public discussion. This could lead to the false impression that the members of the Bundesrat, i.e., members of the German Länder governments, just meet at the plenary session and cast their votes as instructed by their cabinets. However, when taking a closer look at the Bundesrat process and especially the public bureaucrats involved in the preparation of decisions, it becomes evident that before each plenary meeting, there are several weeks of intense exchange of information, coordination and pre-negotiation among Länder governments. The Bundesrat is an arena of horizontal IGR.

Despite a long tradition of research on the German Bundesrat, it has only recently been described and analyzed in terms of IGR (Auel 2014; Lhotta and von Blumenthal 2015; Hegele and Behnke 2017). Little is known about the process of intergovernmental coordination in the Bundesrat and many questions are still open. What happens during the coordination process? How do the members of the Bundesrat coordinate with each other? Building on research which shows that the interests of the Länder governmental actors play a role in Bundesrat decisions (Leunig and Träger 2014; Bräuninger, Gschwend, and Shikano 2010), this article conceptualizes three interest dimensions of sub-state governmental actors, namely sectoral, territorial, and political party dimensions, and analyzes their consequences for the conduct of the coordination process. I then theoretically elaborate and empirically test which of these coordination strategies prevails over the others, thereby also including a time factor. For this purpose, first, the German Bundesrat and its coordination process are described in detail. Second, I develop an analytical framework of multidimensional interests in intergovernmental relations and formulate hypotheses about the effects of these interests for the coordination process. Third, after laying out the general research design and describing the newly collected network dataset, I present the results of the empirical analysis regarding how these multidimensional interests play out in the coordination process. By systematically analyzing the Bundesrat through the lens of IGR, these findings have a high potential for international comparison.

\section{The Case of the German Bundesrat}

The Bundesrat is the German second chamber through which the Länder governments directly participate in federal legislation (Article 50 Basic Law). The Bundesrat holds important veto rights in federal legislation. When the 
administrative power of the Länder and their finances are affected as well as for constitutional changes, the consent of the (qualified) majority of the votes in the Bundesrat is even mandatory for ratification (Article 52, 77 Basic Law). The Bundesrat thus holds an absolute veto in these cases which constitute up to 40 percent ${ }^{1}$ of federal legislation. In all other cases, it can call a mediation committee and has at least a suspensory veto that can severely delay the process but be overruled with a Bundestag majority (Article 77 Basic Law). Additionally, the Bundesrat itself can initiate federal law (Article 76 (1) Basic Law). The Länder in the Bundesrat have three to six votes, depending on their population. These votes need to be cast uniformly by each Land; separation of votes is not possible, and abstentions are equal to "no" votes (Article 51 Basic Law). ${ }^{2}$

The majority requirement for the consent or dismissal of a federal motion or the invocation of the mediation committee triggers intergovernmental coordination between the Länder. Since its establishment, a three-week sequence of Bundesrat preparation has evolved (Schrenk 2010). In the first week, the committees of the Bundesrat meet. There are sixteen Bundesrat committees, organized around policy sectors and roughly mirroring the layout of the federal ministries. ${ }^{3}$ The main purpose of these committees is to exchange information about the positions of the Länder departments on a federal motion. The committee gives recommendations of approval, change or dismissal of the motion to the plenary of the Bundesrat. In the second week, the coordination week, the results of the committee discussions are further analyzed and coordinated. If agreement was not reached within the committee or if a motion was discussed in several committees, the Länder engage in intensive coordination and try to find compromise or allies in order to win a majority in the Bundesrat plenary. In the third week, final coordination and the plenary voting take place.

The actors engaged in these processes are usually high-ranking public officials with a special responsibility for coordination. Each department has at least one unit for Bundesrat coordination or IGR. These units usually staff the Bundesrat committees (Sturm and Müller 2013, 146-48). Each Land also nominates a minister or a senior civil servant to 'Representative to the Federal State' (Bevollmächtigter beim Bund) who is responsible for Bundesrat coordination of the Land as a whole. He or she usually heads a division or a section in the government chancellery. ${ }^{4}$ Additionally, the Representative is the head of the Land Representation (Landesvertretung) in Berlin, which is also an organizational unit of the government chancellery. The Land Representations coordinate Bundesrat decisions onsite in Berlin with the other Länder and the federal state (Zerr 2006; Schrenk 2010). These coordination units in the departments together with their ministers and the government chancelleries with the prime minister are the main actors involved in Bundesrat coordination and hence are the unit of analysis in this study. 
The German Bundesrat was selected as a case of analysis for two reasons. First, scholars have only begun to conceptualize it as an arena of IGR (Auel 2014; Lhotta and von Blumenthal 2015) but there are still many open questions. By focusing on intergovernmental coordination within the Bundesrat and embedding it into a wider framework of analysis, the potential for international comparison of this aspect of the Bundesrat becomes evident. Second, actors act in a situation of compulsory joint decision-making without exit-options. Hence, there are high incentives to actively participate and engage in coordination relations without the strategic threat to exit. Thereby, the focus of IGR is directed from the usual question of 'why do they coordinate' to the next step of 'how do they coordinate.'

\section{Theoretical Framework and Hypotheses}

Coordination is referred to as a process, not an outcome (Peters 1998), during which actors prepare a joint decision or action. Coordination is conceptualized as the "intervening stage of debate and deliberation [during which] persuasion, reconsideration, conceivably even coercion takes place" (Shepsle and Boncheck $1997,44)$ before a joint decision is taken. Instead of focusing on the circumstances under which consistent polices are achieved (Hustedt and Veit 2014), this article emphasizes the importance of "strategies and instruments governments use to coordinate organizations or programs within the public sector" (Bouckaert, Peters, and Verhoest 2010, 16). Simplifying Metcalfe's (1994) nine-step to a three-step coordination scale, the process of coordination is conceptualized as the exchange of information, the positioning of actors, and the negotiation of compromise or decisions.

IGR are processes of interaction between executive actors at different levels within a federal or multilevel system. Federal and sub-state government actors interact with each other for several reasons, such as the exchange of best-practices and information, the coordination of policies or the resolution of conflict (Poirier, Saunders, and Kincaid 2015). Scholarship on IGR concentrates mostly on the vertical relations between the federal government and sub-states (e.g., Marks, Hooghe, and Schakel 2008), but IGR also occur horizontally among the sub-states (e.g., Bowman 2004; Zimmerman 2011), and this is the focus of the present contribution. In this perspective, sub-states cannot merely be treated as one unit opposing the federal government, but need to be conceptualized as individual actors with their own interests and goals (e.g., Nugent 2009; Simeon 2006). Disaggregating even further, governments consist of several governmental actors, i.e., ministers belonging to different parties in coalition governments and their bureaucracy who also can pursue differing goals. Hence, in order to really understand processes of intergovernmental coordination it is necessary to consider these governmental actors as unit of analysis. 
IGR are influenced by institutions and rules (Bolleyer, Swenden, and McEwen 2014a), but they are more accurately described as informal, day-to-day and handson information, coordination and negotiation relations within federal states. Actors have a certain strategic leverage in conducting these intergovernmental coordination processes in order to accomplish their interests and goals within the institutional context and boundaries set to them (Scharpf 1997). This strategic leverage is most obvious in the choice of coordination partners in IGR. Most IGR processes are characterized by a multitude of participating governmental actors. Due to several constraints such as time and information, it is very unlikely that each of the actors coordinate with each other actor. Instead, it can reasonably be assumed that actors strategically choose coordination partners with whom the transaction costs are low and the benefits of coordination are high. This expectation is underpinned by the insights of homophily theory, which theorizes "that a contact between similar people occurs at a higher rate than among dissimilar people" (McPherson, Smith-Lovin, and Cook 2001, 416). The rationale behind this commonly observed phenomenon is the fact that exchange and communication are easier and more effective with similar other actors due to a similarity of perceptions, interpretations, and goals (Rogers and Bhowmik 1970). This similarity leads to lower transaction costs because certain viewpoints along with the framing of the problem and its context are similar among the actors and do not need to be discussed. Furthermore, actors who share similar goals can expect higher benefits from coordination. The agreed-on joint position or decision will be closer to each actors' ideal point due to a higher overlap of interests and goals (i.e., their win sets; Putnam 1993) in the first place. The exchange of information, the finding of a common position, and the negotiation of compromise or joint decisions are easier and more beneficial with similar other actors. When investigating IGR processes in Germany and internationally more closely, however, it becomes evident that the interests of sub-state governmental actors in multilevel systems are not unidimensional. Actors share interests along several dimensions; hence several coordination strategies can be expected. The following paragraphs elaborate on these sectoral, territorial, and political party dimensions of coordination.

\section{Sectoral Coordination}

Sectoral $^{5}$ coordination takes place between actors with similar portfolio responsibility. This is based on the specialization, expertise, and sectoral interests of governmental actors (Nugent 2009, 27). Governmental departments make policy within their respective sphere of responsibility. Environmental laws are prepared and executed by the departments for the environment, social laws by the departments for social affairs, and so forth. This does not only pertain to policy 
that sub-states exercise within their jurisdiction but also when participating in multilevel policy-making. Hence, if issues in their portfolio are on the intergovernmental agenda, the departments are involved as well (Johns, O'Reilly, and Inwood 2007). It only seems logical that they contact the departments of the same sector in the other sub-states and from horizontal "brotherhoods of experts" (Wagener 1979). This sectoral orientation is further reinforced by the different interests and goals between the sectors. Issues very often overlap sectoral borders and a policy might have environmental, economic, and social implications at the same time and thus all the affected departments want and need to have a say in the decision-making process. This can lead to discussion or even competition between the sectors (Bardach 1996; Page 2006). Hence, coordination with actors with whom they share a sectoral affiliation is on the one hand not only easier due to shared expertise but also supposedly more beneficial due to similar interests and goals. Pursuing these together-and possibly against other sectors-makes their claim even stronger.

Hypothesis 1a: If two actors share the same sectoral affiliation, they are more likely to coordinate with each other due to joint expertise.

\section{Territorial Coordination}

Sub-state governmental actors also pursue territorial interests. These are "institutional self-interests of Länder governments in the preservation and expansion of their resources and competences" (Scharpf 1985, 334, own translation), interests in "what is best for their states as states [...] in their dealings with the federal government" (Nugent 2009, 20) and the other sub-states. Scholarly literature has demonstrated that sub-states are more likely to coordinate and enter joint agreements if they share some characteristics, such as language (Bochsler 2009). Territorial conflict in Germany is not as severe as in other federal states, for example Spain, the UK, or Canada, whose federal integrity and stability are threatened by this conflict dimension (Amoretti and Bermeo 2004). In contrast, in the German constitution as well as in the federal culture there is a deeply entrenched norm about realizing an equivalence of living conditions throughout the whole federation. However, despite the de jure symmetry of the Länder, there are de facto asymmetries which intensified since reunification (Auel 2014) leading to several territorial cleavages in the German federal system.

The financial cleavage exists between the net contributors and net receivers in the federal equalization scheme. Traditionally, a small number of Länder (Bavaria, Baden-Württemberg, Hesse, and sometimes Hamburg) are net contributors and the other twelve or thirteen Länder are net receivers in federal equalization, ${ }^{6}$ leading the Länder governments to develop different interests (e.g., 
Heinemann et al. 2015). Especially regarding federal policy with Länder participation through the Bundesrat, the net contributors typically prefer less federal state involvement since they are more capable of financing policy on their own whereas the net receivers often are dependent on the-financial-involvement of the federal state. This has been pronounced not only during the reform debates of the German federal reform of 2006 (Scharpf 2008, 512; Kropp and Behnke 2016) and the ongoing negotiations about the reform of the fiscal equalization scheme, but it is also important in day-to-day policy making in the Bundesrat.

A second territorial cleavage continues to exist between the Eastern (former GDR) and the Western Länder based on the weaker economic situation of the Eastern Länder (Jeffery 2008, 590; Kropp and Behnke 2016, 13). It has been observed that the Eastern Länder especially have established their own meetings and coordination rounds prior to the meetings of the intergovernmental councils (Auel 2014, 429). Hence it can be expected that they also uphold close coordination relations with each other during the Bundesrat preparations.

A third territorial cleavage can be expected between the geographically very small but densely populated city-states (Berlin, Hamburg, and Bremen) and other more territorially extended sub-states. These two types of sub-states typically face different kinds of problems and are differently affected by federal state policy. The city-states on the one hand have a denser population and a higher concentration of taxpaying corporations, but on the other hand have relatively higher expenditures for social security and infrastructure (public transportation, hospitals, schools), which is also provided for the surrounding areas despite the lack of tax revenue (Kropp 2010a, 99). Due to this specific problem structure common to city-states, it can be expected that they engage in close coordination relations with each other.

Hypothesis 1b: If two actors share similar territorial characteristics, they are more likely to coordinate with each other due to similar economic or financial interests.

\section{Political Party Coordination}

IGR are carried out by executives and governments; hence party politics and the coordination of party interests are a relevant factor. Party politics help structure the process by creating "ideological grouping and uniting interests" (Esselment 2013,720 ) among actors with similar ideological or political party affiliations. In this respect, the party system of the multilevel state matters. The German party system is vertically integrated and symmetric (Detterbeck and Renzsch 2003); there are several party families which are close associations between organizations at the federal and the sub-state level. ${ }^{7}$ Rooted in their ideological point of view, these party families usually have different interests and goals regarding how policy 
should be formulated. Hence, coordination between members of the same party family should be very frequent.

Political party coordination in the Bundesrat has mainly been discussed in a vertical direction, with some scholars arguing that the federal state government or opposition parties try to use their majorities in the Bundesrat to support or block legislation and with some scholars assessing whether political party or Länder interests prevail (Bräuninger, Gschwend, and Shikano 2010; Lehmbruch 2000; Leunig and Träger 2014). In a horizontal direction, it has been observed that the political parties repeatedly meet (in so called A- [Social Democrats], B- [Christian Democrats] and recently also G- [Greens] meetings ${ }^{8}$ to coordinate their positions in the Bundesrat (Schrenk 2010; Leonardy 2002; Auel 2014). These observations presuppose high coordination activity between political party peers.

Hypothesis 1c: If two actors share the same political party affiliation, they are more likely to coordinate with each other due to similar ideological viewpoints.

\section{Territorial versus Party Coordination}

The question of whether territorial or political party interests prevail in intergovernmental relations has long attracted the interest of federalism scholars. According to Esselment (2013, 704), classical federalism scholars were already divided on this question. Simeon on the one hand argues that "The Canadian party system [...] fails to provide an adequate mechanism for federal-provincial coordination in policy-making" (Simeon 2006, 31). Riker on the other hand states that "the structure of the party system [...] may be regarded as the main variable intervening between the background social conditions and the specific nature of the federal bargain" $(1964,136)$. These scholars as well as recent investigations (Jensen 2017; Nugent 2009; Bolleyer, Swenden, and McEwen 2014b; Esselment 2013) hint at a varying relation between and prevalence of these interest dimensions between multilevel systems and over time. This also makes it necessary to conduct an assessment of the relation between these interest dimensions in Germany. Generally, political party coordination is argued to be less conflictual, and hence more important, the more congruent government compositions are (Bolleyer, Swenden, and McEwen 2014b).

In Germany, Lehmbruch (2000) first hinted at the effects of party politics on intergovernmental relations, with several other researchers taking up this question for empirical investigation (Bräuninger, Gschwend, and Shikano 2010; Leunig 2012). Recent findings suggest that party politics play a minor role in the German multilevel system compared to territorial interests of the Länder (Auel 2014; Hegele and Behnke 2017; Leunig and Träger 2014). In German federalism, political party coordination has become more complicated over time because of a growing 
heterogeneity of government compositions. The governments of the German Länder are usually coalition governments made up of two or three parties. Traditionally, these governments were either led by the Social Democrats (SPD) together with the Greens (B90/Grüne) or the Christian Democrats in coalition with the Liberals (FDP). During the last decade, this has changed dramatically. The number of Grand Coalitions comprised of the CDU and the SPD has increased, and in some Länder the Greens, the Liberals (FDP) or the Lefts (LINKE) serve as coalition partners in varying constellations (Kropp 2010b; Auel 2014). As a result, the variation in the composition of Länder governments, which also determine the composition of the Bundesrat, increased. This has consequences for political party coordination in the Bundesrat. With the increasing heterogeneity of government compositions, the A-/B-coordination meetings also become more complex. In the A-meeting, for example, there are SPD ministers who are either in a coalition with the Greens, the Lefts, or the CDU. Despite the ongoing strong vertical integration of the party system, this increasing diversity of coalition governments at the federal and Länder level can be expected to make party coordination less important. This is in line with the observation that political party interests rarely crowd out genuine 'Länder interests' (Leunig and Träger 2014). In contrast, territorial differences are still present in recent German federalism and, if anything, aggravated after reunification and in light of the economic and financial crises (Auel 2014). Hence, it can be expected that in recent German federalism, territorial coordination is more important than political party coordination.

Hypothesis 2: Territorial coordination is more important than political party coordination due to the increasing heterogeneity of government composition alongside the persistence of territorial differences.

\section{Sequencing Coordination Strategies}

Generally, the simultaneity of these three interest dimensions creates a complex decision situation for the individual as well as the group of actors as a whole. An actor's sectoral, party, and territorial interests might be in line with each other but just as likely might contradict each other or impose different requirements on the decision to be taken. This conceptualization thus emphasizes an aspect of joint decision situations previously often neglected. Classically, complex joint decision situations are characterized by a high number of actors or a high number of decision alternatives. Complexity can hence be reduced by a reduction of either actors or alternatives (Scharpf, Reissert, and Schnabel 1976). The trichotomy of interest dimensions however creates a different sort of complexity. Interest dimensions cannot just be reduced or abolished. Instead, a gradual step-by-step focusing on each of them separately, which will be called sequencing in the 
following, is a reasonable alternative. Sequencing in this context refers to a notional separation of the interest dimensions in a time-ordered sequence. Actors do not try to take into account all of their possibly contradicting interest dimensions at once, but focus on each of them separately. During the process of preparation of a joint decision, this leads to the sequential use of coordination strategies. This argument is in line with literature on the importance of timing and sequencing for political decisions (Goetz and Meyer-Sahling 2009; Pierson 2000).

Among the three interest dimensions and coordination strategies elaborated above, sectoral coordination is the least conflictual. It is based on an interest in making effective sectoral policy using expert and technical knowledge. Furthermore, in an intergovernmental decision situation, sectoral expertise is available to each sub-state. Hence, if all sectoral actors come to a joint decision based on technical and expert knowledge, this issue can in most cases be regarded as being solved and will be passed to the plenary for a final voting. In contrast, party and territorial interests are based less on technical considerations than on political arguments, and only a sub-population of the sub-states, e.g. only those governed by a certain party, shares them. Hence, agreement between members of one party or one territorial grouping cannot be regarded as a compromise by all sub-states. Therefore, it can be expected that sectoral coordination takes place first. Only when it is not successful in bringing about a decision will political party or territorial coordination become relevant and aim at building a majority in the later phases of the coordination process.

Hypothesis 3: The coordination strategies are used in a time-ordered sequence, first sectoral and second political party as well as territorial coordination.

\section{Research Design and Data}

The aim of this article is to investigate the coordination strategies of governmental actors in IGR with the example of the German Bundesrat. This on the one hand requires a complete conceptualization of the actors and coordination processes but on the other hand also knowledge about strategic considerations made by actors. To satisfy these two requirements, a multi-method approach is used. Coordination is first measured with a network dataset. Coordination is a relational action which takes place between two actors who exchange information and try to find a common position or compromise. With the use of network analytic methods this relational aspect can appropriately be captured. The advantage of this data is its encompassing information on all the actors involved and their relations to each other. In order to triangulate the results, additional expert interviews were then conducted with a focus on the rationale behind the use of the coordination strategies. 
The network dataset was collected by the author in an online survey among the Länder governmental actors in Germany from August to November 2015. The survey was sent out to all 171 governmental organizations of the Länder. ${ }^{9}$ This time point was chosen to avoid during data collection a switch of the Bundesrat presidency which takes place in November. Furthermore, no federal or Land elections fall into the survey period; thus the composition of the Bundesrat is stable. Respondents were asked about their direct coordination partners during the preparation of Bundesrat decisions. Showing to the respondents a list of possible contact partners by position (not by name), they were asked to "Please indicate, with whom of the following actors you have contact during the preparation of the Bundesrat." In order to stimulate a similar understanding of coordination contacts across respondents, they were given a definition at the beginning of the survey: "By coordination contacts, we mean communication very broadly which: a) takes place in preparation of Bundesrat meetings, b) consists of routinized multi-actor or bilateral communication, c) can take several forms such as personal meetings, the exchange of calls, text messages, social media or emails." Furthermore, it was acknowledged that "With whom you coordinate of course depends on the current agenda. For this reason, please try to indicate the relevant contacts which you had during the last year." In a second step, they were presented with a table of the chosen actors and the three weeks of the Bundesrat cycle: "You have indicated that you have contact to the following actors. During which of the three weeks of the Bundesrat cycle does this contact take place? (multiple answers possible)." The relations reported by the actors can be interpreted as a mean value of typical coordination contacts over the last year. If respondents have not indicated a coordination contact with another actor, this either means that no coordination takes place or that it is not relevant to the actor.

According to Rice et al. (2014, 253), three main problems can arise when collecting network data with a survey: boundary specification, recall bias, and nonresponse. Boundary specification in this study is not a problem because the bureaucrats who are responsible for preparing multilevel decisions in the government chancelleries, in the Land representations in Berlin and in the ministries of all Länder is a finite group of actors which can be identified using a position selection procedure in the charts of the respective organizations. ${ }^{10}$ Recall bias is more of a problem with free recall name generators. Taking advantage of the clearly defined network boundaries, a roster design was implemented which presented the actors with a full list of possible coordination partners (Marsden and Marsden 2005, 9f.). This minimizes recall bias by making respondents think of each possible contact partner and decide whether coordination takes place or not. A response rate of 65 percent (112 out 171 organizations) was achieved. In order to obtain the highest response rate possible, several steps were taken before and during the field phase of the survey. Before the field phase, the hierarchically 
Table 1 Nonresponse analysis

\begin{tabular}{lccc}
\hline & Response & Total (=group size) & Response rate (\%) \\
\hline Organization (all) & 112 & 171 & 65 \\
Government Chancellery & 14 & 16 & 88 \\
Land Representation & 14 & 16 & 88 \\
Ministries & 84 & 139 & 60 \\
Länder & 16 & 16 & 100 \\
Organization within each Land & $4-9$ & $9-13$ & $40-90$ \\
Policy Sector & $8-14$ & 16 & $50-88$ \\
Party affiliation & $5-58$ & $8-87$ & $62-67$ \\
Financial situation (contributor/receiver) & $19 / 40$ & $46 / 125$ & $59 / 68$ \\
Geographical location (east/west) & $17 / 42$ & $62 / 109$ & $73 / 63$ \\
Geographical spread (city/area) & $18 / 41$ & $34 / 137$ & $47 / 70$ \\
\hline
\end{tabular}

highest bureaucrat was informed about the research project, open questions were discussed and concerns addressed. During the field phase, response was monitored on a regular basis and Länder with lower than average response rate were reminded of the survey. Analysis of the nonresponses further shows that no systematical gaps in responses occur along the relevant dimensions of the study such as type of organization, sector, political party, or territorial characteristics (Table 1).

In order to triangulate the findings from the social network analysis and to capture the strategic element of coordination, six expert interviews were conducted by the author with ministerial bureaucrats responsible for Bundesrat coordination. Interviews were recorded, transcribed and analyzed with CAQDAS (atlas.ti) using topical coding (Hopf 2000).

\section{Empirical Analysis}

\section{Description of the Network}

The surveyed coordination network of the ministerial bureaucracy of the German Länder consists of 171 actors and 2,245 reported coordination relations between actors. The relations are directed, i.e., there are two possible relations between any two actors. The network consists of one component with no isolates meaning that each actor is at least indirectly connected to every other actor. The overall density of the network is 0.07 indicating that 7 percent of all possible relations between two actors are realized. This rather low density supports the assumptions that actors make choices about their coordination partners. Out of the 2,245 relations, 446 dyads are mutual, i.e., 60 percent of the relations are not reciprocated. In the mean, the actors have thirteen in- and outgoing coordination relations, 
respectively. The in-degree distribution of the network indicates that there are a small number of actors who are only contacted by less than five actors and more than twenty actors; most of the actors are contacted by between five and twenty other actors. The out-degree distribution on the contrary indicates a high number of actors who only have five or less outgoing contacts. These contain among a few others the missing responses from which only incoming but no outgoing contacts are known. Those actors who have responded mainly report between ten and twenty-five contacts. Considering the limited resources such as time available to the actors during the coordination process, these numbers are reasonable. During the cycle, the density of the network decreases from 0.5 in the committee week, to 0.4 in the coordination week and 0.3 in the plenary week. This decrease in contacts as coordination proceeds might have different reasons: either certain actors are assigned by a group of actors to further conduct coordination or less coordination is needed because issues are already solved during the first or second week. The fact that during neither week the density is as high as in the full network indicates that certain pairs of actors do not coordinate during the first week and only coordinate during the following weeks, which can be seen as a first indication of the relevance of a time factor during the coordination process.

\section{Quantitative Analysis of the Coordination Strategies}

In order to assess the hypotheses, in a first step the share of homophily relations according to the three coordination strategies is assessed descriptively. This share is calculated using the following formula: $\frac{\text { homophily edges }}{\text { homophily edges + heterophily edges }}$ (Nick et al. 2013).

The results (Table 2) indicate that in each strategy, at least 45 percent of the coordination relations are homophilous. Fifty percent of all coordination relations exist between two actors who share the same sector, 46 percent between two actors who are affiliated to the same political party. In support of hypothesis two, this share is highest for the territorial characteristics. Between 68 percent and 80 percent of all coordination contacts are to actors with a similar financial or geographical location. Comparison over time yields a decrease in sectoral homophily and an increase in political party and territorial homophily, which initially supports hypothesis three.

This counting of homophily ties, however, does not take into account the varying group numbers among coordination strategies which explains the high percentage of territorial homophily. Territorial characteristics are binary (contributor-receiver, east-west, city-state, or not); hence the probability of within-group coordination is higher than among the sectors and political parties. Furthermore, group sizes within each coordination strategy vary considerably, not only with regard to territorial but also political party affiliations. Furthermore, homophily according to territorial and party affiliation might be overestimated 
Table 2 Homophily in the coordination strategies

\begin{tabular}{|c|c|c|c|c|}
\hline \multirow[b]{2}{*}{$\begin{array}{l}\text { Coordination } \\
\text { strategy }\end{array}$} & \multicolumn{4}{|c|}{ Homophily share } \\
\hline & Whole network & $\begin{array}{l}\text { Committee } \\
\text { week }\end{array}$ & $\begin{array}{l}\text { Coordination } \\
\text { week }\end{array}$ & $\begin{array}{l}\text { Plenary } \\
\text { week }\end{array}$ \\
\hline Sectoral & $50 \%(1,130 / 2,245)$ & $51 \%(786 / 1,552)$ & $38 \%(433 / 1,152)$ & $39 \%(346 / 892)$ \\
\hline Financial situation & $68 \%(1,525 / 2,245)$ & $71 \%(1,108 / 1,552)$ & $80 \%(941 / 1,152)$ & $81 \%(730 / 892)$ \\
\hline Geographical location & $73 \%(1,644 / 2,245)$ & $65 \%(1,009 / 1,552)$ & $80 \%(936 / 1,152)$ & $82 \%(736 / 892)$ \\
\hline Geographical spread & $80 \%(1,788 / 2,245)$ & $87 \%(1,212 / 1,552)$ & $86 \%(991 / 1,152)$ & $85 \%(757 / 892)$ \\
\hline Political party & $46 \%(1,037 / 2,245)$ & $46 \%(708 / 1,552)$ & $50 \%(547 / 1,152)$ & $52 \%(466 / 892)$ \\
\hline
\end{tabular}

because several or all of the actors within one Land share these characteristics. Homophily counts further cannot account for network effects such as reciprocity or actor attributes such as participation in the survey.

Those effects and attributes can however be controlled for using exponential random graph models (ERGMs). These are statistical models which are used increasingly in political science. ERGMs treat the observed network as one possible realization and estimate its likelihood in contrast to random realizations of networks, given several properties of the network (Robins et al. 2007). The models account for the interdependency of actors and their ties from other ties in the network, which would cause a problem to standard regression analysis in the form of biased coefficients and inconsistent standard errors (Cranmer and Desmarais 2011). In the network of horizontal intergovernmental coordination, the ties between the actors are not independent of each other because the choice of coordination partners depends on the other coordination relations within the network. First of all, a reciprocity effect can be expected because, in IGR, interaction occurs repeatedly between the same actors and mutual trust relations are likely to develop between several pairs of actors (Axelrod 1984, Scharpf 1992). Second, a popularity effect is a reasonable assumption in a coordination network. Actors want to influence the final decision through their coordination relations; hence they need to talk to influential actors. Influential actors are those who have a lot of coordination relations, because they are able to reach out to a lot of actors. ERGMs offer the possibility to, first, test these dependence assumptions on the empirical data and, second, to use them to specify the model with which the exogenous effects (i.e., homophily according to actor attributes) on the network are tested. The coefficients in ERGMs are log-odds and hence their magnitude cannot be directly interpreted. In the following it will be sufficient to take into account the sign (positive or negative) of the coefficients.

The models estimated (Table 3) support H1a and H1c. Sharing the same sector and political party are important features of the observed network. The existence of 
Table 3 ERGMs for the coordination network

\begin{tabular}{|c|c|c|c|}
\hline & $\begin{array}{l}\text { Endogenous } \\
\text { model }\end{array}$ & $\begin{array}{l}\text { Homophily } \\
\text { model }\end{array}$ & $\begin{array}{c}\text { Full model } \\
\text { (with actor covariates) }\end{array}$ \\
\hline Edges & $\begin{array}{c}-3.846^{* * *} \\
(0.146)\end{array}$ & $\begin{array}{c}-3.561^{\star * *} \\
(0.315)\end{array}$ & $\begin{array}{c}-4.552^{\star * *} \\
(0.744)\end{array}$ \\
\hline Mutual & $\begin{array}{l}2.521^{\star \star \star} \\
(0.072)\end{array}$ & $\begin{array}{l}0.209^{\star} \\
(0.092)\end{array}$ & $\begin{array}{l}0.195^{\star} \\
(0.107)\end{array}$ \\
\hline Popularity & $\begin{array}{l}0.166^{\star * *} \\
(0.026)\end{array}$ & $\begin{array}{c}-0.726^{\star * *} \\
(0.065)\end{array}$ & $\begin{array}{c}-0.935^{* * *} \\
(0.084)\end{array}$ \\
\hline Survey response & - & $\begin{array}{c}2.146^{\star * *} \\
(0.080)\end{array}$ & $\begin{array}{l}2.320^{\star * *} \\
(0.091)\end{array}$ \\
\hline GvtChancellery (Receiver) & - & $\begin{array}{c}0.472^{\star * *} \\
(0.116)\end{array}$ & - \\
\hline GvtChancellery (Sender) & - & $\begin{array}{c}-0.200^{\star *} \\
(0.072)\end{array}$ & - \\
\hline Same Land & - & $\begin{array}{l}3.820^{\star * *} \\
(0.100)\end{array}$ & $\begin{array}{c}4.073^{\star * *} \\
(0.110)\end{array}$ \\
\hline Same sector & - & $\begin{array}{l}3.157^{\star * *} \\
(0.074)\end{array}$ & $\begin{array}{l}3.316^{\star * *} \\
(0.078)\end{array}$ \\
\hline Same political party & - & $\begin{array}{c}0.363^{\star * *} \\
(0.057)\end{array}$ & $\begin{array}{c}0.469^{* * *} \\
(0.069)\end{array}$ \\
\hline Same financial situation & - & $\begin{array}{l}-0.011 \\
(0.064)\end{array}$ & $\begin{array}{c}-0.188^{\star *} \\
(0.081)\end{array}$ \\
\hline Same geographical location & - & $\begin{array}{l}0.106^{*} \\
(0.062)\end{array}$ & $\begin{array}{c}0.172^{* * *} \\
(0.066)\end{array}$ \\
\hline Same geographical spread & - & $\begin{array}{c}0.019 \\
(0.072)\end{array}$ & $\begin{array}{l}-0.057 \\
(0.097)\end{array}$ \\
\hline Sectors as sender and receiver & - & $\begin{array}{l}- \\
-\end{array}$ & Included \\
\hline Parties as sender and receiver & - & - & Included \\
\hline Territorial characteristics as sender and receiver & - & - & Included \\
\hline Akaike Inf. Crit. & 14,783 & 9,610 & 9,190 \\
\hline Bayesian Inf. Crit. & 14,808 & 9,710 & 9,521 \\
\hline
\end{tabular}

Note: ${ }^{*} p<0.1 ;{ }^{* *} p<0.05 ;{ }^{* *} p<0.01$, estimations are performed using the $\mathrm{R}$ statnet package (Handcock et al. 2016), table created with Stargazer (Hlavac 2015).

Note: In this model, the sectors, political parties, and territorial characteristics are included as actor covariates in order to control for effects which stem from the mere affiliation to one of the groups. Due to the high number of sectors and parties, this model however exceeds the space of the table. The following interpretations are only based on the reported values for homophily. The government chancelleries are excluded from the model because they also constitute a sector. 
a tie between two such actors is significantly higher in the existing network than in a random network; this effect is stable across model specifications. If two actors are working in the same sector or are affiliated with the same party family, coordination contacts between them are more likely. Sectoral and political party coordination strategies indeed are used by actors when preparing Bundesrat decisions. Furthermore, contacts between actors are more likely when they are part of the same Land, and government chancelleries are contacted with a higher likelihood than other actors. Territorial coordination however is less strong than expected, and certainly weaker than political party coordination. Being situated in the same geographical location, i.e. east or west of Germany slightly increases the likelihood of coordination contacts. However, being in a similar financial situation (contributor-receiver) or having a similar geographical spread (city-states) does not determine the choice of coordination partners. Hence, despite the growing heterogeneity of government party composition and the persistence of territorial differences, in the overall network political party coordination is more important than territorial coordination, thus contradicting hypothesis two. This finding is discussed further in light of the expert interviews below.

In the next step, the homophily model is calculated separately for each of the three weeks of the Bundesrat process-the committee week, the coordination week and the plenary week-in order to test hypothesis three. The results in Table 4 indicate that during all three weeks, sectoral and political party coordination constantly plays an important role. Territorial coordination, or at least the eastwest aspect of it, becomes more important during the coordination process. The closer the final decision, the more likely departments from Eastern and Western Länder use their respective territorial coordination strategy. This partially supports hypothesis three regarding the growing importance of territorial coordination.

The sectoral coordination strategies are worth investigating in greater depth. Sectoral coordination needs to be interpreted against the background of the growing importance of government chancelleries as senders and receivers of coordination contacts during the process. When operationalizing sectoral homophily, the government chancelleries were treated as a 'sector' on their own, in order to avoid missing data and to ensure the comparability of the coordination strategies. The growing importance of the government chancellery (Table 4) hence indicates a decreasing importance of the departments with special portfolio responsibility along the process of Bundesrat preparations. During the first week of the Bundesrat process, the sectoral departments play a much stronger role than the government chancelleries, i.e., sectoral coordination takes place primarily between ministries with portfolio responsibility. This coordination is characterized by a high degree of specialization and expert knowledge. By the end of the cycle, the government chancelleries are important coordination partners. Government chancelleries, as the centers of government and bureaucratic organizations of the 
Table 4 ERGMs during the Bundesrat coordination process

\begin{tabular}{|c|c|c|c|}
\hline & \multicolumn{3}{|c|}{ Dependent variable } \\
\hline & Committee week & Coordination week & Plenary week \\
\hline Edges & $\begin{array}{c}-4.535^{\star \star *} \\
(0.272)\end{array}$ & $\begin{array}{c}-5.901^{\star * *} \\
(0.337)\end{array}$ & $\begin{array}{c}-7.178^{\star * *} \\
(0.295)\end{array}$ \\
\hline Mutual & $\begin{array}{c}0.107 \\
(0.112)\end{array}$ & $\begin{array}{l}-0.005 \\
(0.139)\end{array}$ & $\begin{array}{c}0.158 \\
(0.143)\end{array}$ \\
\hline Popularity & $\begin{array}{c}-0.478^{\star * *} \\
(0.065)\end{array}$ & $\begin{array}{c}-0.663^{\star * *} \\
(0.094)\end{array}$ & $\begin{array}{c}-0.256^{\star * *} \\
(0.088)\end{array}$ \\
\hline Survey Response & $\begin{array}{c}1.788^{\star * *} \\
(0.081)\end{array}$ & $\begin{array}{c}1.962^{* * *} \\
(0.102)\end{array}$ & $\begin{array}{l}1.434^{* * *} \\
(0.098)\end{array}$ \\
\hline GvtChancellery (Receiver) & $\begin{array}{c}-1.095^{\star * *} \\
(0.128)\end{array}$ & $\begin{array}{l}1.101^{\star * *} \\
(0.164)\end{array}$ & $\begin{array}{c}0.960^{\star * *} \\
(0.172)\end{array}$ \\
\hline GvtChancellery (Sender) & $\begin{array}{c}-0.684^{\star * \star} \\
(0.092)\end{array}$ & $\begin{array}{l}-0.029 \\
(0.101)\end{array}$ & $\begin{array}{c}0.560^{* * *} \\
(0.093)\end{array}$ \\
\hline Same Land & $\begin{array}{c}2.979^{\star * *} \\
(0.102)\end{array}$ & $\begin{array}{c}4.771^{\star * *} \\
(0.146)\end{array}$ & $\begin{array}{c}4.175^{\star * *} \\
(0.138)\end{array}$ \\
\hline Same sector & $\begin{array}{c}2.852^{\star * *} \\
(0.080)\end{array}$ & $\begin{array}{c}2.855^{\star * *} \\
(0.108)\end{array}$ & $\begin{array}{c}2.484^{\star * *} \\
(0.110)\end{array}$ \\
\hline Same political party & $\begin{array}{c}0.369^{\star * *} \\
(0.062)\end{array}$ & $\begin{array}{c}0.322^{\star * *} \\
(0.079)\end{array}$ & $\begin{array}{c}0.358^{\star * *} \\
(0.084)\end{array}$ \\
\hline Same financial situation & $\begin{array}{c}0.011 \\
(0.073)\end{array}$ & $\begin{array}{l}-0.153 \\
(0.102)\end{array}$ & $\begin{array}{c}-0.059 \\
(0.114)\end{array}$ \\
\hline Same geographical location & $\begin{array}{c}0.052 \\
(0.073)\end{array}$ & $\begin{array}{c}0.290^{\star * *} \\
(0.093)\end{array}$ & $\begin{array}{c}0.502^{\star * *} \\
(0.110)\end{array}$ \\
\hline Same geographical spread & $\begin{array}{c}0.016 \\
(0.085)\end{array}$ & $\begin{array}{l}-0.096 \\
(0.109)\end{array}$ & $\begin{array}{l}-0.155 \\
(0.112)\end{array}$ \\
\hline Akaike Inf. Crit. & 8,450 & 5,491 & 4,844 \\
\hline Bayesian Inf. Crit. & 8,549 & 5,590 & 4,944 \\
\hline
\end{tabular}

Note: ${ }^{*} p<0.1 ;{ }^{* *} p<0.05 ;{ }^{* *} p<0.01$, estimations are performed using the $\mathrm{R}$ statnet package (Handcock et al. 2016), table created with Stargazer (Hlavac 2015).

prime ministers and the whole cabinet, in their organization unite all three interest dimensions and become more important during the process. This finding also supports hypothesis three stating that in a coordination sequence, sectoral coordination takes place first. This is further supported by the observation that coordination within the same Land is least important in the first week, where actors supposedly focus on sectoral coordination and less than in the following weeks on cross-sectoral coordination also within their own Land. 
During the whole process, political party peers are in constant exchange and coordination with each other, and political party coordination is stronger than territorial coordination. This finding is investigated below based on the results of the expert interviews.

\section{Discussion and Expert Interviews}

Statistical analysis with ERGMs has revealed that sectoral and political party coordinations are more pronounced strategies than territorial coordination during the coordination process. This finding can be explained by an overly broad conceptualization of territorial interest, such as contributor versus receiver or east versus west. According to the interviews, Länder coordination is more oriented towards common policy interests of Länder, which might be rooted in territorial characteristics. In energy policy, for example, different Länder favor different energy sources, based on their energy industry and natural resources. Two neighboring Länder both might be economically dependent on coal production and hence are likely to coordinate closely when it comes to energy policy due to similar territorial interest (Land Representation Sachsen 2013). Another example mentioned by interviewees is flood protection, where Länder recently affected by a flood coordinated closely despite different government parties (Land Representation Sachsen 2013). These effects cannot be captured with broad characterizations of territorial characteristics, but are specific to the issues discussed.

The overall existence of political party coordination during all stages of the coordination process as found in the statistical analysis can be explained by their structuring effect on the coordination process. As early as in the committee week, the departmental actors pre-coordinate their positions with their political party peers from the same sector prior to the committee meetings as well as with their political party peers in their own Land (Land Representation Sachsen 2013; Land Representation of Bremen 2013). The discussions however are still very much dominated by technical questions and regulation details requiring foremost the expert knowledge of the departments (Land Representation of Baden-Württemberg 2013). Also during later stages of the coordination process, the traditional A-, Band G- meetings still take place (Government Chancellery Baden-Württemberg 2013). Even though they have become more heterogeneous, their persistence indicates that they fulfil an important structuring effect during the coordination process. This explains why the network data indicates a higher relevance of party coordination and thus contradicts hypothesis two. Political party coordination is an important factor in structuring the coordination process in all stages, a finding which is in line with recent literature on party politics in IGR (Esselment 2013). 
Regarding the sequence of coordination strategies, the interviewees reported unanimously that approximately 95 percent of the topics decided on by the Bundesrat are only coordinated sectorally by the policy experts (Government Chancellery Baden-Württemberg 2013; Land Representation Sachsen 2013; Government Chancellery of Berlin 2013). In these cases, after the committee week, a clear and uncontroversial recommendation by the responsible committee(s) is sent to the plenary where it serves as decision memo and hardly any further discussion takes place. This also underpins the lesser importance of the government chancelleries as coordination partners found in the ERGMs during the committee week. There are nevertheless issues which are discussed or disputed more intensely in the Bundesrat. First, these are issues where conflict between departments or policy sectors exists (Government Chancellery Baden-Württemberg 2013; Land Representation Sachsen 2013). In such instances, sectoral coordination will not bring a result, and coordination with the other Länder, i.e., party or territorial coordination, is needed. Second, when the issue under discussion is politically highly salient, party or territorial coordination become important as well (Land Representation Sachsen 2013; Government Chancellery Baden-Württemberg 2013). In this situation, the actors coordinate with the aim of finding a Bundesrat majority which best represents their interests. This mainly takes place during the coordination week or sometimes can only be resolved in the plenary week (Land Representation of Baden-Württemberg 2013). The existence of several coordination strategies at hand during the second and third week gives the actors strategic leeway for building a majority. The options available to actors in IGR are usually not dichotomous choices between 'yes' and 'no,' but they have a whole continuum of slight changes and reformulations of the policy at their disposal. Hence, actors can try to actively compose a majority consisting of different actors with which they share different overlaps of interests. Therefore, it might be strategically advantageous to simultaneously use party as well as territorial coordination strategies to discover or develop the best alliance during the second and third week of the coordination process.

\section{Conclusion}

This analysis has systematically conceptualized three interest dimensions of actors in horizontal IGR: on a sectoral dimension actors possess detailed expert knowledge which they use during policy-making; on a territorial dimension characteristics such as the financial or geographical situation of a Land lead to certain preferences regarding the final decisions; on a political party dimension, ideologically rooted differences exist between the actors. The empirical data have shown that all three interest dimensions are important during the horizontal coordination process. Ministerial bureaucrats tend to engage in coordination 
relations with other actors who are similar to them regarding their sectoral, territorial, or political party affiliation at a higher rate. The two main findings from this analysis are first that in the recent German multilevel system, political party coordination is still important but rather has a structuring function, and second that sectoral coordination is an important but so far often neglected aspect of multilevel coordination.

To elaborate on each of these conclusions, despite the increased heterogeneity of government party compositions, party affiliation still determines the choice of coordination partners, even at a bureaucratic level. However, party coordination takes place with the aim of structuring the process. It is used as a strategy to reduce the complexity arising from the high number of actors during the coordination process (Scharpf, Reissert, and Schnabel 1976). Hence, party coordination in the course of the Bundesrat appears to fulfil a functional rather than a substantial or political role. This expands the finding by Esselment (2013) that parties matter during the process of intergovernmental coordination and provides evidence that their effect, at least in Germany, prevails over territorial interests in terms of structuring the coordination process. The growing importance of territorial coordination during the process, however, indicates a truly substantial and political usage of the territorial coordination strategy.

Second, during the course of the coordination process, actors first engage in sectoral coordination where they try to find solutions based on technical and expert knowledge of the subject. This coordination seems to be successful in the majority of instances, and very often no further coordination is needed. This observation indicates that sectoral coordination in intergovernmental relations has a high potential for the resolution of inter-jurisdictional conflict and needs closer consideration by scholars as well as practitioners. A common orientation and knowledge background of sectoral actors can facilitate coordination and solve problems which might otherwise be subject to political capture. This supports initial findings indicating that sectoral conferences in multilevel systems might be able to help overcome political deadlock (León and Ferrín Pereira 2011). Only under certain circumstances, namely when there is cross-sectoral conflict or an issue has high political salience, do German multilevel actors engage in more conflict-laden territorial or party coordination strategies.

\section{Notes}

I would like to thank all the participants of the online survey as well as the interviewees for the time they invested. Many thanks also go to the anonymous reviewers, the editor as well as Nathalie Behnke for their valuable feedback and comments.

1. This is the case since the reform of the federal system in 2006. Before the reform, 5060 percent of the drafts needed the consent of the second chamber. See: http://www. Bundesrat.de/DE/dokumente/statistik/statistik-node.html. 
2. Further research on the vertical role of the Bundesrat in relations to the federal government and especially the federal government parties will not be discussed here because the focus of this article is on the horizontal coordination structures in the Bundesrat. For a recent overview, see Stecker (2016).

3. http://www.bundesrat.de/DE/bundesrat/ausschuesse/ausschuesse-node.html.

4. Government chancellery is used as the generic term for the German public organizations responsible for administering the affairs of the head of government and the cabinet as a whole (Bundeskanzleramt, Staats- und Senatskanzleien) (MüllerRommel 2003; Fleischer 2011).

5. I refer here to sectoral interests and coordination, not to policy interests, because the argument and data are on the level of institutionalized sectors as we find them in departments and parliamentary committees. Coordination in the environmental sector therefore takes place between the ministries of the environment when discussing several environmental policies.

6. This system is currently in a process of reform, but was still in place at the time of data collection.

7. There are differences between some sub-state parties from the same party family (Bräuninger and Debus 2011), but these will be neglected here for the sake of simplicity.

8. A- and B-meetings are just named after the rooms in which they first met.

9. Government chancelleries, Land Representations, and departments in autumn 2015.

10. Their responsibility for Bundesrat coordination within the organization was identified by searching for 'Bund', 'Bundesrat', 'föderale Beziehungen', 'Zentralstelle', 'Dienststellenleiter' in their job title or title of their section. This list was then sent out to the contact partners in each Land to verify the responsibilities before sending out invitations for the online survey.

\section{References}

Amoretti, Ugo M., and Nancy Gina Bermeo. 2004. Federalism and territorial cleavages. Baltimore, MD: Johns Hopkins University Press.

Auel, Katrin. 2014. Intergovernmental relations in German federalism: Cooperative federalism, party politics and territorial conflicts. Comparative European Politics 12 (4-5): 422-443.

Axelrod, Robert M. 1984. The evolution of cooperation. New York, NY: Basic Books.

Bardach, Eugene. 1996. Turf barriers to interagency collaboration. In The state of public management, ed. Donald F. Kettl and H. Brinton Milward, 168-192. London: John Hopkins University Press.

Behnke, Nathalie, and Sabine Kropp. 2016. Arraying institutional layers in federalism reforms: Lessons from the German case. Regional \& Federal Studies 26 (5): 585-602.

Bochsler, Daniel. 2009. Neighbours or friends? When Swiss cantonal governments co-operate with each other. Regional \& Federal Studies 19 (3): 349-370. 
Bolleyer, Nicole, Wilfried Swenden, and Nicola McEwen. 2014a. Constitutional dynamics and partisan conflict: A comparative assessment of multi-level systems in Europe. Comparative European Politics 12 (4-5): 531-555.

2014b. A theoretical perspective on multi-level systems in Europe: Constitutional power and partisan conflict. Comparative European Politics 12 (4-5): 367-383.

Bouckaert, Geert, B. Guy Peters, and Koen Verhoest. 2010. The coordination of public sector organizations. Shifting patterns of public management. Basingstoke: Palgrave Macmillan.

Bowman, Ann O’M. 2004. Horizontal federalism: Exploring interstate interactions. Journal of Public Administration Research and Theory 14 (4): 535-546.

Bräuninger, Thomas, and Marc Debus. 2011. Parteienwettbewerb in den deutschen Bundesländern. Wiesbaden: VS.

Bräuninger, Thomas, Thomas Gschwend, and Susumu Shikano. 2010. Sachpolitik oder Parteipolitik?. Politische Vierteljahresschrift 51 (2): 223-249.

Cranmer, Skyler J., and Bruce A. Desmarais. 2011. Inferential network analysis with exponential random graph models. Political Analysis 19 (1): 66-86.

Detterbeck, Klaus, and Wolfgang Renzsch. 2003. Multi-level electoral competition: The German case. European Urban and Regional Studies 10 (3): 257-269.

Esselment, Anna Lennox. 2013. A little help from my friends: The Partisan factor and intergovernmental negotiations in Canada. Publius: The Journal of Federalism 43 (4): 701-727.

Fleischer, Julia. 2011. Steering from the German centre: More policy coordination and fewer policy initiatives. In Steering from the centre. Strengthening political control in western democracies, ed. Carl Dahlström, B. Guy Peters and John Pierre, 54-79. Toronto: University of Toronto Press.

Goetz, Klaus H., and Jan-Hinrik Meyer-Sahling. 2009. Political time in the EU: Dimensions, perspectives, theories. Journal of European Public Policy 16 (2): 180-201.

Government Chancellery Baden-Württemberg. 2013. Interview with author. September 10.

Government Chancellery of Berlin. 2013. Interview with author. September 9.

Handcock, M., D, Hunter, C, Butts, S, Goodreau, P, Krivitsky, S, Bender-deMoll, and M, Morris. 2016. Statnet: Software tools for the statistical analysis of network data. The Statnet Project.

Hegele, Yvonne, and Nathalie Behnke. 2017. Horizontal coordination in cooperative federalism: The purpose of ministerial conferences in Germany. Regional \& Federal Studies 1-20. doi: 10.1080/13597566.2017.1315716.

Heinemann, Friedrich, Eckhard Janeba, Marc-Daniel Moessinger, and Christoph Schröder. 2015. Who likes to fend for oneself? Revenue autonomy preferences of subnational politicians in Germany. Publius: The Journal of Federalism 45 (4): 653-685.

Hlavac, Marek. 2015. Stargazer: Well-formatted regression and summary statistics tables. R package version 5.2. http://CRAN.R-project.org/package=stargazer. 
Hopf, Christel. 2000. Qualitative interviews - Ein Überblick. In Qualitative forschung, ed. Uwe Flick, Ernst von Kardoff and Ines Steinke, 349-360. Reinbek: Rowohlt.

Hustedt, Thurid, and Silvia Veit. 2014. Forschungsperspektiven auf Regierungs- und Verwaltungskoordination: Koordinationsprobleme und Erklärungsfaktoren. Dms - Der Moderne Staat 7 (1): 17-36.

Jeffery, Charlie. 2008. Groundhog day: The non-reform of German federalism, again. German Politics 17 (4): 587-592.

Jensen, Jennifer M. 2017. Governors and Partisan polarization in the federal arena. Publius: The Journal of Federalism 47 (3): 314-341.

Johns, Carolyn M., Patricia L. O'Reilly, and Gregory J. Inwood. 2007. Formal and informal dimensions of intergovernmental administrative relations in Canada. Canadian Public Administration 50 (1): 21-41.

Kropp, Sabine. 2010a. Kooperativer Föderalismus und Politikverflechtung. Wiesbaden: VS.

- 2010b. The ubiquity and strategic complexity of grand coalition in the German federal system. German Politics 19 (3-4): 286-311.

Kropp, Sabine, and Nathalie Behnke. 2016. Marble cake dreaming of layer cake: The merits and pitfalls of disentanglement in German federalism reform. Regional \& Federal Studies 26 (5): 667-686.

Land Representation of Baden-Württemberg. 2013. Interview with author. July 10.

Land Representation of Bremen. 2013. Interview with author. October 6.

Land Representation Sachsen. 2013. Interview with author. September 24.

Lehmbruch, Gerhard. 2000. Parteienwettbewerb im Bundesstaat. Regelsysteme und Spannungslagen im politischen System der Bundesrepublik Deutschland. Wiesbaden: Westdeutscher.

León, Sandra, and Mónica Ferrín Pereira. 2011. Intergovernmental cooperation in a decentralised system: The sectoral conferences in Spain. South European Society and Politics 16 (4): 513-532.

Leonardy, Uwe. 2002. Parteien im Föderalismus der Bundesrepublik Deutschland. Scharniere zwischen Staat und Politik. Zeitschrift Für Parlamentsfragen 33 (1): 180-195.

Leunig, Sven. 2012. Parteipolitik und Landesinteressen. Der deutsche Bundesrat 1949 - 2009. Münster; Berlin: LIT.

Leunig, Sven, and Hendrik Träger. 2014. Landesinteressen, Parteipolitik, "Parteidruck" - der Bundesrat im Fokus divergierender Interessen. Zeitschrift Für Politikwissenschaft 24 (1-2): 55-81.

Lhotta, Roland, and Julia von Blumenthal. 2015. Intergovernmental relations in Germany: Complex co-operation and party politics. In Intergovernmental relations in federal systems: Comparative structures and dynamics, ed. Johanne Poirier, Cheryl Saunders and John Kincaid, 206-238. Ontario, Canada: Oxford University Press.

Marks, Gary, Liesbet Hooghe, and Arjan H. Schakel. 2008. Measuring regional authority. Regional \& Federal Studies 18 (2-3): 111-121. 
Marsden, Peter V., and Peter V. Marsden. 2005. Recent developments in network measurement: Models and methods in social network analysis. New York: Cambridge University Press.

McPherson, Miller, Lynn Smith-Lovin, and James M. Cook. 2001. Birds of a feather: Homophily in social networks. Annual Review of Sociology 27: 415-444.

Metcalfe, Les. 1994. International policy co-ordination and public management reform. International Review of Administrative Sciences 60 (2): 271-290.

Müller-Rommel, Ferdinand. 2003. Management of politics in the German chancelor's office. In Administering the summit. Administration of the core executive in developed countries, ed. B. Guy Peters, R.A.W. Rhodes and Vincent Wright, 81-100. Basingstoke: Palgrave Macmillan.

Nick, Bobo, Conrad Lee, Pádraig Cunningham, and Ulrik Brandes. 2013. Simmelian backbones: Amplifying hidden homophily in facebook networks. Proceedings of the IEEE/ ACM International Conference on Advances in Social Networks Analysis and Mining (ASONAM '13): 525-532.

Nugent, John Douglas. 2009. Safeguarding federalism: How states protect their interests in national policymaking. Norman: University of Oklahoma Press.

Page, Edward C. 2006. Joined-up government and the civil service. In Joined-up government, ed. Vernon Bogdanor, 139-156. Oxford: Oxford University Press.

Peters, B. Guy. 1998. Managing horizontal government: The politics of co-ordination. Public Administration 76 (2): 295-311.

Pierson, Paul. 2000. Not just what, but when: Timing and sequence in political processes. Studies in American Political Development 14 (1): 72-92.

Poirier, Johanne, Cheryl Saunders, and John Kincaid, ed. 2015. Intergovernmental relations in federal systems. Comparative structures and dynamics. Forum of Federations. Ontario, Canada: Oxford University Press.

Putnam, Robert D. 1993. Diplomacy and domestic politics. The logic of two-level games. In Double-edged diplomacy. International bargaining and domestic politics, ed. Peter B. Evans, Harold K. Jacobson and Robert D. Putnam, 43-468. Berkeley: University of California Press.

Rice, Eric, Ian W. Holloway, Anamika Barman-Adhikari, Dahlia Fuentes, C. Hendricks Brown, and Lawrence A. Palinkas. 2014. A mixed methods approach to network data collection. Field Methods 26 (3): 252-268.

Riker, William Harrison. 1964. Federalism: Origin, operation, significance. Boston, MA: Little Brown.

Robins, Garry, Pip Pattison, Yuval Kalish, and Dean Lusher. 2007. An introduction to exponential random graph $\left(\mathrm{p}^{*}\right)$ models for social networks. Social Networks 29 (2): 173-191.

Rogers, Everett M., and Dilip K. Bhowmik. 1970. Homphily-heterophily: Relational concepts for communication research. Public Opinion Quarterly 34 (4): 523-538. 
Scharpf, Fritz. 1985. Die Politikverflechtungs- Falle: Europäische integration und deutscher Föderalismus im Vergleich. Politische Vierteljahresschrift 26 (4): 323-356. 1997. Games real actors play: Actor-centered institutionalism in policy research. Boulder, CO: Westview Press.

. 2008. Community, diversity and autonomy: The challenges of reforming German federalism. German Politics 17 (4): 509-521.

Scharpf, Fritz, Bernd Reissert, and Fritz Schnabel. 1976. Politikverflechtung: Theorie und Empirie des kooperativen Föderalismus in der Bundesrepublik. Kronberg: Scriptor.

Scharpf, Fritz W. 1992. Koordination durch Verhandlungssysteme. Analytische Konzepte und institutionalle Lösungen. In Horizontale Politikverflechtung. Zur Theorie von Verhandlungssystemen., ed. Arthur Benz, Fritz W. Scharpf and Reinhard Zintl, 51-96. Frankfurt/New York: Campus.

Schrenk, Klemens. 2010. Die Vertretungen der Länder beim Bund. In Analyse demokratischer Regierungssysteme, ed. Klemens Schrenk and Markus Soldner, 359-374. Wiesbaden: VS.

Shepsle, Kenneth A., and Mark S. Boncheck. 1997. Analyzing politics: Rationality, behavior, and institutions. New York: W. W. Norton \& Company.

Simeon, Richard. 2006. Federal-provincial diplomacy: The making of recent policy in Canada. Toronto: Univ. of Toronto Press.

Stecker, Christian. 2016. The effects of federalism reform on the legislative process in Germany. Regional \& Federal Studies 26 (5): 603-624.

Sturm, Roland, and Markus M. Müller. 2013. Blockadepolitik in den Ausschüssen des Bundesrates - Offene Fragen und erste Antworten. In Jahrbuch des Föderalismus 2013, ed. Europäisches Zentrum für Föderalismus-Forschung Tübingen, 142-154. Baden-Baden: Nomos.

Wagener, Frido 1979. Der Öffentliche Dienst im Staat der Gegenwart. Veröffentlichung Der Vereinigung Der Deutschen Staatsrechtslehrer 37: 215-266.

Zerr, Michael. 2006. Staatskanzleien. In Landespolitik in Deutschland. Grundlagen Strukturen - Arbeitsfelder, ed. Herbert Schneider and Hans-Georg Wehling, 185-206. Wiesbaden: VS.

Zimmerman, Joseph Francis. 2011. Horizontal federalism. Interstate relations. Albany: State University of New York Press. 